Available online on 15.03.2020 at http://jddtonline.info
Open Access to Pharmaceutical and Medical Research
unrestricted non-commercial use, provided the original work is properly cited

Open Access

Research Article

\title{
Acute and Sub-acute Toxic Effects of Algerian Peganum harmala L. Crud Extract
}

\author{
Abir Rezzagui *1,2, Mounira Merghem ${ }^{3}$, Ismahane Derafa ${ }^{3}$, Saliha Dahamna ${ }^{3}$ \\ ${ }^{1}$ Laboratory of Applied Biochemistry : Oxidative stress and Inflammation. Faculty of Natural and Life Sciences. University Ferhat Abbas. Sétif - \\ 19000 Algeria \\ 2 Department of Biological and Molecular Biology. University of Jijel. Jijel - 18000 Algeria \\ ${ }^{3}$ Laboratory of Phytotherapy Applied to Chronic Diseases. Department of Animal Biology and Physiology. Faculty of Natural and Life Sciences. \\ University Ferhat Abbas. Sétif - 19000 Algeria
}

\begin{abstract}
The present study was carried out to evaluate the acute and sub-acute toxicity of Algerian Peganum harmala L. seeds (Zygophyllaceae). For the acute toxicity assessment, oral administration of $P$. harmala crud extract to mice in single doses of $0-12 \mathrm{~g} / \mathrm{kg}$ caused dose-dependent general behavior adverse effects and mortality with $\mathrm{LD}_{50}$ of $2,86 \mathrm{~g} / \mathrm{kg}$. In the sub-acute study, daily oral administration of the crude aqueous extract for 28 consecutive days did not result no mortality. However, our results showed a significant difference in organs weights between contr ol and treated animals. In the biochemical analysis, significant changes occurred in Bilirubin, uric acid (UA) and alkaline phosphatase (ALP) in the treated animals when compared to the control ones. Hematological analysis showed differences in WBC count and Hemoglobin estimation However, urinalysis was negative for all parameters except Glucose in the treated group. Pathologically, a few gross abnormalities and histological changes were observed in hepatic and nephritic tissues.
\end{abstract}

Keywords: Peganum harmala L., Acute and Sub-Acute Toxicity, Hematological parameters, Biochemical parameters

Article Info: Received 05 Jan 2020; Review Completed 19 Feb 2020; Accepted 27 Feb 2020; Available online 15 March 2020

$\square: \operatorname{rit}: \square$ Cite this article as:

Rezzagui A, Merghem M, Derafa I, Dahamna S, Acute and Sub-acute Toxic Effects of Algerian Peganum harmala L. Crud Extract, Journal of Drug Delivery and Therapeutics. 2020; 10(2):115-121 http://dx.doi.org/10.22270/jddt.v10i2.3920

*Address for Correspondence:

Rezzagui Abir, Laboratory of Oxidative stress and Inflammation. Faculty of Natural and Life Sciences. University Ferhat Abbas. Sétif - 19000 Algeria

\section{INTRODUCTION}

Medicinal plants are believed to be an important source of chemical substances with potential therapeutic effects. Thus, studying of traditional medicinal plants used as pain killers should be sees as a logical strategy in search for new drugs. Peganum harmala L. (Zygophyllaceae), commonly known in Algeria as Harmel, is one of Algerian medicinal plants that grow in semi-arid conditions, steppe areas and sandy soils [1]. It is mainly found in eastern Mediterranean region, Central Asia, North Africa and Middle East [2]. In folk medicine, the seeds are known to possess abortive, emmenagogue, narcotic, anti-spasmodic, anti-asthmatic, anti-rheumatism and anti-cancer properties [3]. There are several reports in the literature indicating a great variety of pharmacological activity for $P$. harmala L. extracts: analgesic [4], anti-nociceptive [5], hypoglycemic [6], vasorelaxant [7], antioxidant [8], anti-microbial [9], anti-helminthic [2], antiHSV [10], and cytotoxic properties [1].
However, all parts of this plant, especially seeds, are thought to be toxic and sever intoxication symptoms like hypothermia, vomiting, respiratory troubles, hallucination and convulsions were occurred in domestic animals and few human cases $[11,12]$.

Many studies reported that a wide spectrum of beneficial and toxicological effects of $P$. harmala is attributed to the presence of many bioactive compounds: fixed oils $[13,14]$ saponins [15], polyphenols [8] and alkaloids which are the major compound with up of $10 \%$ of the total seeds dry weight. These alkaloids are mainly comprised of $\beta$-carboline and quinazoline derivatives, including Harman, Harmine, Harmaline [16], Peganine and Desoxypeganine $[17,18]$. The $\beta$-carboliniques alkaloids have neuro-pharmacological and toxicological effects such as: deactivation of Monoamine Oxidase type A (MAO-A), inhibition of the recapture of serotonin and agonist of serotonin and dopamine receptors $[19,20$ and 21]. Furthermore, the studies of Tuliaganov et al. [22] showed that quinazoline alkaloids were inhibitors of the 
acetyl-cholinesterase (AChE): the responsible enzyme in the degradation of acetylcholine.

In the present study, we evaluate the toxicological effects to define the safe dose of the seeds of $P$. harmala and protect the users from their possible toxic effects. Furthermore, this is the first time $P$. harmala crud extract has been studied in short-term oral administration for hepatic and nephrotoxicity on the biochemical and histological levels in mice.

\section{MATERIALS AND METHODS}

\section{Plant material}

Peganum harmala seeds were purchased from a local herbal medicine store of Wilaya of Mila - Algeria in September 2012. The plant was authenticated by Pr. Laouar H. Department of Vegetal biology - Faculty of Natural and Life Sciences - University Ferhat Abbas - Sétif, Algeria.

\section{Experimental animals}

Male and female Albino Swiss mice (3 months old, weighting $29.21 \pm 2.79 \mathrm{~g})$ were obtained from Pasteur Institute (Algiers, Algeria). These animals were kept in an airconditioned animal room at the animal house of the Nature and Life Sciences Faculty - University of Sétif with natural photoperiod cycle. The animals were housed in plastic cages ( 5 animals per cage with separation of both sexes) and had free access to standard commercial diet and tap water.

\section{Preparation of $P$. harmala extract}

The seeds of $P$. harmala were cleaned, air-dried and ground to a powder using a manual grinder. Crud extract was prepared by adding $100 \mathrm{~g}$ of seed powder to 1 liter of methanol/distilled water mixture (80/20) for 24 hours and the resulting macerate was filtered using Wattman paper $n^{\circ} 3$. These steps were repeated another time. The resulting filtrate was evaporated in rotary vacuum evaporator at $45^{\circ} \mathrm{C}$ to get the crud extract (CE).

\section{Acute toxicity study of the Crud extract (CE)}

In this study, CE was administered orally using 7 groups of mice ( 10 mice of both sexes in each group) at singles doses of $0,0.1,0.5,1,3,6$ and $12 \mathrm{~g} / \mathrm{kg}$ of body weight. The behavioral changes and signs of toxicity and/or mortality of mice was monitored directly after dosing, periodically during the first 24 hours (with special attention given during the first 6 hours), then daily for a total period of 14 days [23]. Lethal dose value (LD50) was determined using Miller and Trainer method (1944) according to Randhawa [24].

\section{Sub-acute toxicity study of CE}

Female mice were divided into two groups of 8 mice each; treated and control group. The treated group received CE daily by gavage at dose of $285.8 \mathrm{mg} / \mathrm{kg} /$ day for 28 consecutive days. Whereas, control group received only the distilled water during the treatment period. Toxic manifestations and mortality were monitored daily, and the body weight changes were recorded every day [25].

\section{Organ's weight}

After blood collection, animals were euthanized with diethyl ether and their vital organs such as liver, kidneys, heart, lungs, spleen, brain and stomach were carefully dissected out, rinsed with $0.9 \% \mathrm{NaCl}$ solution and weighed individually (absolute organ weight).

\section{Blood analysis}

At the end of the 28-day period, animals were anesthetized slightly by diethyl ether and blood was collected by cardiac puncture in two tubes: one with ethylene di-amine tetraacetate (EDTA) and the other with heparin. EDTA tube was processed immediately for hematological parameters analysis and the heparinized blood was centrifuged at 4000 $\mathrm{rpm}$ at $4 \mathrm{C}^{\circ}$ for $10 \mathrm{~min}$ to obtain serum (stored at $-20^{\circ} \mathrm{C}$ until biochemical analysis).

Analysis of hematological parameters including: red blood cell (RBC), white blood cell (WBC), hemoglobin, hematocrit, mean corpuscular hemoglobin concentration (MCHC), mean corpuscular volume (VGM), platelets and mean platelet volume (MPV), was performed using automatic hematological analyzer (Beckman Coulter ${ }^{\circledR}$ - AcT diff 2). For biochemical analysis, the serum was analyzed for cholesterol (CHOL), glucose, creatinine, aspartate aminotransferase (AST), alanine aminotransferase (ALT), triglycerides (TG), uric acid (UA), alkaline phosphatase (ALP), bilirubin and total Proteins (TP). Dosages were made using automatic analyzer (Beckman Coulter ${ }^{\circledR}$ AU680).

\section{Urine simples}

Urine samples $(0.5-1.5 \mathrm{ml})$ were collected during 2-4 hours for each animal in a metabolic cage. Urinalysis was undertaken using urine test strip Siemens® (Multistix 8 SG).

\section{Liver and kidney tissues histopathological examination}

Fresh rinsed liver and kidney tissues of all animals were fixed in buffered formaldehyde solution (10\%), dehydrated by serial ethanol solution (70-90\%), cleared in xylene and enclosed with paraffin. Five micrometers sections, cut by a microtome (Carl Zeiss® Jena), were stained with hematoxylin-eosin [26] and examined under a light microscope; photomicrographs of the samples were recorded.

\section{Statistical analysis}

All results are expressed as the mean value \pm standard deviation. The Student's t-test was used to assess the differences between data. Differences were considered significant at $\mathrm{p}<0.05$. Statistical analyses were performed with GraphPad Prism 5®.

\section{RESULTS}

\section{Acute toxicity}

The results of the toxicity study of CE given orally as single doses are presented in Table 1. The adverse effects and lethality increased progressively with increasing oral doses from 0.1 to $12 \mathrm{~g} / \mathrm{kg}$. Some adverse effects, such as hypoactivity, piloerection, trembling, breathing difficulty, bradycardia, diffuse tremors and convulsions were observed immediately after administration. They were more pronounced at higher doses $(3,6$ and $12 \mathrm{~g} / \mathrm{kg})$ and persisted until death. Toxic effects, mortality and latency appeared to be gender-depending where the males being more sensitive than females. The acute toxicity data indicated that the calculated $\mathrm{LD}_{50}$ value of $\mathrm{CE}$ was $2.86 \pm 1.17 \mathrm{~g} / \mathrm{kg}$. 
Table 1. Toxic effects, mortality and latency of the CE administered orally as one single dose in mice of both sexes.

\begin{tabular}{|c|c|c|c|c|}
\hline $\begin{array}{l}\text { Dose } \\
(\mathrm{g} / \mathrm{kg})\end{array}$ & Sex & $\begin{array}{l}\text { Death } \\
(\mathrm{D} / \mathrm{T})\end{array}$ & Adverse effects & $\begin{array}{l}\text { Latency } \\
\text { (h/mn) }\end{array}$ \\
\hline 0 & $\begin{array}{l}M \\
F\end{array}$ & $\begin{array}{l}0 / 5 \\
0 / 5\end{array}$ & $\begin{array}{l}\text { None } \\
\text { None. }\end{array}$ & - \\
\hline 0.1 & $\begin{array}{l}M \\
F\end{array}$ & $\begin{array}{l}0 / 5 \\
0 / 5\end{array}$ & $\begin{array}{l}\text { None. } \\
\text { None. }\end{array}$ & - \\
\hline 0.5 & $\begin{array}{l}\mathrm{M} \\
\mathrm{F}\end{array}$ & $\begin{array}{l}0 / 5 \\
0 / 5\end{array}$ & $\begin{array}{l}\text { Hypoactivity, piloerection, anorexia. } \\
\text { Hypoactivity }\end{array}$ & $30 \mathrm{mn}$ \\
\hline 1 & $\begin{array}{l}\mathrm{M} \\
\mathrm{F}\end{array}$ & $\begin{array}{l}1 / 5 \\
0 / 5\end{array}$ & Hypoactivity, piloerection, anorexia, bradycardia, trembling, breathing difficulties. & $47 \mathrm{~h}$ \\
\hline 3 & $\begin{array}{l}\mathrm{M} \\
\mathrm{F}\end{array}$ & $\begin{array}{l}3 / 5 \\
1 / 5\end{array}$ & $\begin{array}{l}\text { Permanente hypo-activity, piloerection, anorexia, bradycardia, trembling, } \\
\text { breathing difficulties, dyspnea and convulsions. }\end{array}$ & $3 h-41 h$ \\
\hline 6 & $\begin{array}{l}\mathrm{M} \\
\mathrm{F}\end{array}$ & $\begin{array}{l}4 / 5 \\
4 / 5\end{array}$ & $\begin{array}{l}\text { Permanente hypo-activity, piloerection, anorexia, bradycardia, trembling, } \\
\text { breathing difficulties, dyspnea, convulsions, loss of balance, muscular spasms, } \\
\text { narcosis with occasional periods of excitations leading to the death. }\end{array}$ & $2 \mathrm{~h}-11 \mathrm{~h}$ \\
\hline 12 & $\begin{array}{l}\mathrm{M} \\
\mathrm{F}\end{array}$ & $\begin{array}{l}5 / 5 \\
5 / 5\end{array}$ & $\begin{array}{l}\text { Permanente hypo-activity, piloerection, anorexia, bradycardia, trembling, } \\
\text { breathing difficulties, dyspnea, convulsions, loss of balance, muscular spasms, } \\
\text { narcosis with occasional periods of excitations leading to the death. }\end{array}$ & $\begin{array}{l}10 \mathrm{mn}- \\
27 \mathrm{~h}\end{array}$ \\
\hline
\end{tabular}

$\mathrm{F}$ : female ; $\mathrm{M}$ : male ; T : total ; D : death ; h : hour ; mn : minute

\section{Sub-acute toxicity studies}

\section{Clinical observations and body weight}

Daily oral administration of CE for 28 consecutive days did not produce any obvious symptoms of toxicity or mortality
(Table 2). Compared to the baseline value, no significant change was observed in body weight between treated and control animals, except a slight weight gain in the week 4 .

Table 2. Effect of sub-acute oral administration of CE on body weight.

\begin{tabular}{|c|c|c|c|c|}
\hline \multirow{2}{*}{ WEEKS } & \multicolumn{2}{|c|}{ Control } & \multicolumn{2}{c|}{ Treated } \\
\cline { 2 - 5 } & Body weight (g) & Weight gain (\%) & Body weight (g) & Weight gain (\%) \\
\hline W 1 & $33.58 \pm 1.36$ & $0.83 \pm 0.2$ & $32.12 \pm 2.47 \mathrm{~ns}$ & $0.63 \pm 1.11 \mathrm{~ns}$ \\
\hline W 2 & $35.32 \pm 1.15$ & $1.73 \pm 0.87$ & $32.67 \pm 2.95 \mathrm{~ns}$ & $0.55 \pm 1.79 \mathrm{~ns}$ \\
\hline W 3 & $34.53 \pm 0.84$ & $0.95 \pm 0.79$ & $32.26 \pm 3.14 \mathrm{~ns}$ & $0.14 \pm 1.83 \mathrm{~ns}$ \\
\hline W 4 & $36.31 \pm 1.46$ & $2.73 \pm 0.83$ & $33.14 \pm 3.41^{\mathrm{ns}}$ & $1.01 \pm 0.75^{*}$ \\
\hline
\end{tabular}

Values are expressed as mean \pm SD ( $n=8$ /group). W1-W4: Weeks of the study. ${ }^{n s} p>0.05 ;^{*} p<0.05$ when compared to the control group (Student's $t$-test).

\section{Effect of CE on hematological and biochemical parameters}

The values for the hematological and biochemical parameters in treated and control animals are presented in Table 3 and 4, respectively. Oral administration of CE for 28 consecutive days did cause anemia with a low significant decrease of $23 \%$ and $12 \%$ in RBC and Hemoglobin, respectively $(\mathrm{P}<0.05)$. However, a significant increase of 144
$\%(\mathrm{P}<0.01)$ in $\mathrm{WBC}$ was noticed in the blood of treated animals when compared to the control ones. Similarly to the hematological analysis, a high significant change was observed in the level of UA, followed by a significant change in ALP and Bilirubin levels. On the other hand, the sub-acute treatment with $285.8 \mathrm{mg} / \mathrm{kg}$ did not show any significant differences in the hepatic enzymes (ASAT and ALAT). 
Table 3. Effect of sub-acute oral administration of CE on biochemical parameters in treated and control animals after 28 days.

\begin{tabular}{|l|c|c|}
\hline Parameter & Control & Treated \\
\hline Glucose (g/L) & $1,34 \pm 0,31$ & $1,28 \pm 0,11^{\mathrm{ns}}$ \\
\hline ALAT (UI/L) & $23,33 \pm 6,66$ & $27,2 \pm 3,83 \mathrm{~ns}$ \\
\hline ASAT (UI/L) & $152,33 \pm 18,77$ & $168 \pm 28,87 \mathrm{~ns}$ \\
\hline ALP (UI/L) & $42,7 \pm 6,67$ & $74,4 \pm 8,17^{* *}$ \\
\hline Creatinin (mg/L) & $4,33 \pm 0,57$ & $4,5 \pm 1^{\mathrm{ns}}$ \\
\hline UA (mg/L) & $12 \pm 3,46$ & $42,8 \pm 6,83^{* * *}$ \\
\hline TP (g/L) & $70,15 \pm 6,83$ & $70,12 \pm 6,97 \mathrm{~ns}$ \\
\hline Bilirubin (mg/L) & $1 \pm 0,40$ & $1,4 \pm 0,2^{*}$ \\
\hline TG (g/L) & $1,07 \pm 0,46$ & $0,65 \pm 0,10 \mathrm{~ns}$ \\
\hline Cholesterol (g/L) & $1,08 \pm 0,37$ & $1,04 \pm 0,22^{\mathrm{ns}}$ \\
\hline
\end{tabular}

Values are expressed as mean \pm SD ( $n=8$ /group). ${ }^{* *} \mathrm{p}<0.001 ;{ }^{* *} \mathrm{p}<0.01 ;{ }^{*} \mathrm{p}<0.05 ; \mathrm{ns} \mathrm{p}>0.05$ compared to the control group (Student's ttest ). ALAT: alanine amino-transferase, ASAT: aspartate amino-transferase, ALP: alkaline phosphatase, UA: uric acid, TP: total proteins, TG: triglycerides.

Table 4. Effect of sub-acute oral administration of CE on hematological parameters in treated and control animals after 28 days.

\begin{tabular}{|l|c|c|}
\hline Parameters & Control & Treated \\
\hline RBC $\left(10^{6} / \mathrm{mm}^{3}\right)$ & $9,51 \pm 1,17$ & $6,95 \pm 1,34^{*}$ \\
\hline WBC $\left(10^{3} / \mathrm{mm}^{3}\right)$ & $3,15 \pm 0,49$ & $7,7 \pm 0,98^{* *}$ \\
\hline Platelets $\left(10^{3} / \mathrm{mm}^{3}\right)$ & $1513,5 \pm 516,89$ & $1110,8 \pm 161,19 \mathrm{~ns}$ \\
\hline Hematocrit $(\%)$ & $44,35 \pm 2,19$ & $37,33 \pm 8,43 \mathrm{~ns}$ \\
\hline Hemoglobin $(\mathrm{g} / \mathrm{dL})$ & $14,35 \pm 0,35$ & $12,5 \pm 0,7 *$ \\
\hline MCHC $(\mathrm{g} / \mathrm{dL})$ & $30,75 \pm 1,88$ & $31,3 \pm 2,21 \mathrm{~ns}$ \\
\hline MGV $\left(\mu \mathrm{m}^{3}\right)$ & $56,86 \pm 9,61$ & $49,96 \pm 3,04 \mathrm{~ns}$ \\
\hline MPV $\left(\mu \mathrm{m}^{3}\right)$ & $4,96 \pm 0,43$ & $5,07 \pm 0,40 \mathrm{~ns}$ \\
\hline
\end{tabular}

Values are expressed as mean $\pm \mathrm{SD}$ ( $\mathrm{n}=8$ /group). ${ }^{*} \mathrm{p}<0.05 ;{ }^{* *} \mathrm{p}<0.01$; ${ }^{\mathrm{ns}} \mathrm{p}>0.05$, compared to the control group (Student's $t$-test). RBC: red blood cells count, WBC: white blood cells count, MCHC: mean corpuscular hemoglobin concentration, MGV: mean globular volume, MPV: mean platelet volume.

\section{Urinalysis}

The urinalysis of urine parameters such as specific gravity, $\mathrm{pH}$, glucose, protein, urea acid, ketone, leukocytes and occult blood, did not reveal any changes following sub-acute administration except a significant change on glucose levels in the treated animals when compared to the control ones (Table 5).

\section{Effect of CE on organ's relative weight}

Absolute and relative organ weights of the control and treated animals are shown in Table 6. There was no modification in organs weight except a slight significant change on kidneys relative weight of the treated animals compared to the control ones.

Table 5. Effect of sub-acute oral administration of CE on urine parameters.

\begin{tabular}{|c|c|c|}
\hline Parameter & Control & Treated \\
\hline Glucose $(\mathrm{g} / \mathrm{dL})$ & Negative & $100 \pm 0.0$ \\
\hline
\end{tabular}

Table 6. Effect of sub-acute oral administration of the CE on relative organ's weight in animals after 28 days.

\begin{tabular}{|l|c|c|c|c|}
\hline Organ & \multicolumn{2}{|c|}{ Control } & \multicolumn{2}{c|}{ Treated } \\
\hline Liver & Organ weight & Relative organ weight & Organ weight & Relative organ weight \\
\hline Kidneys & $1.66 \pm 0.17$ & $5.33 \pm 0.64$ & $1.48 \pm 0.22$ & $5.13 \pm 0.49 \mathrm{~ns}$ \\
\hline Heart & $0.38 \pm 0.03$ & $1.21 \pm 0.14$ & $0.40 \pm 0.06$ & $1.39 \pm 0.11^{*}$ \\
\hline Stomach & $0.15 \pm 0.00$ & $0.5 \pm 0.04$ & $0.15 \pm 0.02$ & $0.53 \pm 0.06^{\mathrm{ns}}$ \\
\hline Spleen & $0.35 \pm 0.07$ & $1.14 \pm 0.28$ & $0.31 \pm 0.05$ & $1.09 \pm 0.15^{\mathrm{ns}}$ \\
\hline Lungs & $0.24 \pm 0.03$ & $0.62 \pm 0.07$ & $0.17 \pm 0.05$ & $0.59 \pm 0.12^{\mathrm{ns}}$ \\
\hline Brain & $0.46 \pm 0.04$ & $0.78 \pm 0.08$ & $0.24 \pm 0.02$ & $0.82 \pm 0.08^{\mathrm{ns}}$ \\
\hline
\end{tabular}

Values are expressed as mean $\pm \mathrm{SD}\left(\mathrm{n}=8 /\right.$ group). ${ }^{*} \mathrm{p}<0.01 ;{ }^{\mathrm{ns}} \mathrm{p}>0.05$ compared to the control group (Student's $t$-test). 


\section{Effect of CE on histological morphology of liver and kidney}

Histological examination of the liver and kidney has clearly shown that the cellular and tissular architecture (lobular and tubular) of both organs is well preserved in both control and treated animals. However, some features were considered. Microscopic observation showed a normal liver histological morphology in control group. However, a discrete vascular and sinusoidal congestion, dilated sinusoids and tissue lesion were observed in the liver tissue of some treated animals (Figure 1). Furthermore, sub-acute administration of CE extract revealed the presence of a major vascular congestion, inflammatory infiltrate and cytolysis in some treated animals (Figure 2).
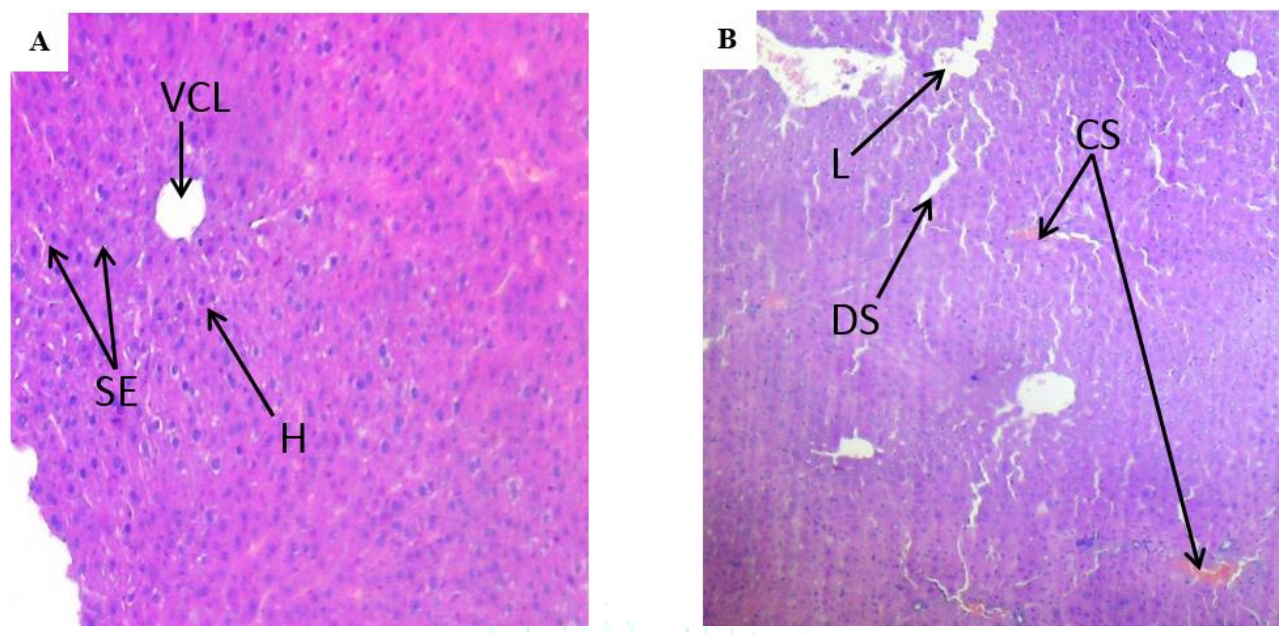

Figure 1. Effects of CE on histological morphology of the liver. A) Control group. B) Treated group. CLV: Centro lobular vein; SE : sinusoid etroit; $\mathrm{H}$ : hepatocyte $; \mathrm{L}$ : tissular lesion; SD : sinusoidal dilatation; SC : sinusoidal congestion
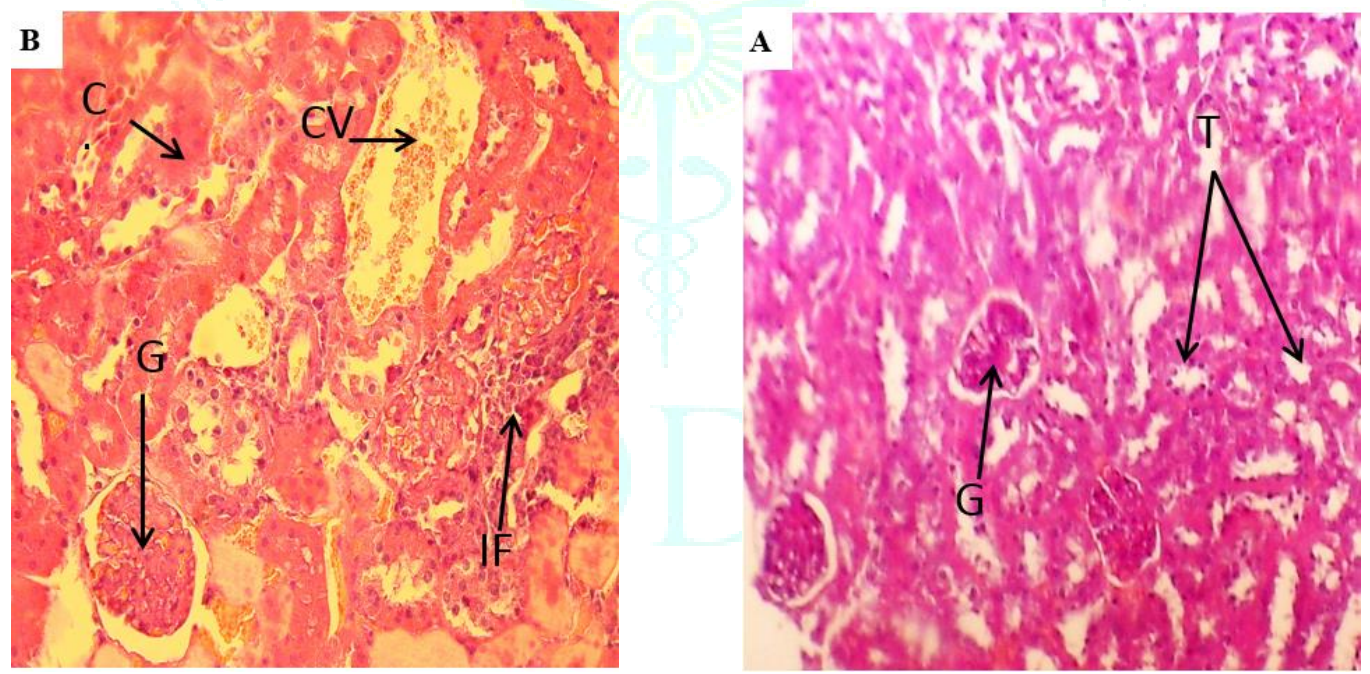

Figure 2. Effects of CE on histological morphology of the kidney. A) Control group. B) Treated group. G : glomeruli ; T : tubule ; VC : vascular congestion; IF : inflammatory infiltrate.

\section{DISCUSSION}

As we reported above, P. harmala could possess a variety of physiological and pharmacological properties. However, a toxicological evaluation needs to be performed to define the safety of $P$. harmala and to protect the users from their possible toxic effects.

Toxicologists usually divide the chemical toxicity into 3 categories: acute, sub-acute and chronic toxicity. Acute toxicity is defined as the exposure of animals to a chemical for less than 24 hours. Sub-acute toxicity refers to repeated exposure to a chemical for 1 month or less and chronic for more than 3 months [27]. In the present study, the period of exposure was less than $24 \mathrm{~h}$ and 28 days, so in this study we used an acute and a sub-acute model, respectively.
In the present study, male and female Albino Swiss mice were orally administered CE of $P$. harmala at single doses of $0,0.1,0.5,1,3,6$ and $12 \mathrm{~g} / \mathrm{kg}$ of body weight in acute toxicity study and daily at a dose of $285.8 \mathrm{mg} / \mathrm{kg}$ of body weight for 28 consecutive days for sub-acute toxicity study. Throughout 14 days of acute study, CE produced toxicity and mortality in mice and $\mathrm{LD}_{50}$ was equal to $2.86 \pm 1.17 \mathrm{~g} / \mathrm{kg}$. According to the classification of Hodge and Sterner [28], chemical substance with a DL50 between 500 and $5000 \mathrm{mg} / \mathrm{kg}$ is considered practically as lightly toxic in humans. Hence, the CE could be considered as a lightly toxic compound. Considering the crud extract yield (20.18\%), it appears that $\mathrm{LD}_{50}$ of CE of $P$. harmala was $14.16 \mathrm{~g}$ of dry seed / $\mathrm{kg}$ of body weight that gives a good safety marge of the use of this plant in traditional medicine. Similar results have been reported in other studies: Lamchouri et al. [29] found that $\mathrm{LD}_{50}$ of the 
aqueous extract of $P$. harmala seeds administered orally in rats was $2.7 \mathrm{~g} / \mathrm{kg}$. On the other hand, the sub-acute toxicity study in female mice receiving CE orally at the dose of 285.8 $\mathrm{mg} / \mathrm{kg}$ during 28 days did not show any signs of intoxication or mortality during the treatment period.

The hematopoietic system is one of the most sensitive targets for toxic compounds, and an important index of physiological and pathological status in human and animals $[30,31]$. Changes in hematological and biochemical system have a higher value for human toxicity, when the data are translated from animal models [32, 33]. Sub-acute exposure of mice of the CE produced a clear modification in some hematological and biochemical parameters which accompanied with significant alteration of the liver and kidney morphology (see later).

Our results showed that $\mathrm{CE}$ has produced a decrease in RBC and $\mathrm{HB}$ and an increase in WBC. Differently, Muhi-eldeen et al. [34] did not show any hematological perturbations during 6 weeks of intramuscular administration of $P$. harmala alkaloids extract in rats. The decrease in RBC and HB may be due to the anemia explicated by an erythropoiesis disorders, decrease of hemoglobin synthesis and/or RBC hemolysis [35]. Several reports have reported the in vitro hemolytic activity of saponins when they were mixed with a RBC suspension [36, 37]. Hence, any plant extracts contains saponins may be produce a sever hemolytic anemia [38]. In fact, El Allagui et al. [15] have already showed that $P$. harmala extracts comprise saponins which the composition and structure are not clearly investigated. Furthermore, the increase of WBC in treated mice refers to reinforcement of the immune system [35]. This suggests that CE contains powerful bioactives substances amplifying the immune system and increasing the rate of WBC: the first defensive level in the organism [39].

Photomicrographs of the sections of the liver and kidney of mice treated orally with the dose of $285.8 \mathrm{mg} / \mathrm{kg}$ for 28 days show a discrete vascular and sinusoidal congestion, dilated sinusoids and tissue lesion in the live, and marked vascular congestion, inflammatory infiltration and cytolysis in the kidney. The hepatotoxicity of $\mathrm{CE}$ is also supported by a marked elevation of alkaline phosphatase (ALP) and Bilirubin with normal levels of transaminases. A different result was reported by Lamchouri et al. [29]: they found that chronic exposure to $P$. harmala alkaloids extracts increased significantly the levels of transaminases (ASAT and ALAT) in rats. This difference may be referred to the treatment period (sub-acute and chronic) or the administered dose (258.8 $\mathrm{mg} / \mathrm{kg}$ and $2000 \mathrm{mg} / \mathrm{kg}$ ). According to Wallace and Meyer, [40], ALP is good indicator of liver function and predicting possible toxicity as well as transaminases (ASAT and ALAT). Generally, ASAT and ALAT found in the serum are of both mitochondrial and cytoplasmic origin. However, ALP is a ubiquitous enzyme particularly in the liver biliary tract, kidney, bones and placenta, where it is highly concentrated. Thus, any significant increase in ALP levels in serum may be due to the presence of an obstruction of the intrahepatic bile ducts, primary biliary cirrhosis or disruption of the liver architecture [41]. Similarly, Bilirubin (a breakdown product of hemoglobin) may be another indicator in the assessment of liver function. Hyper-bilirubin level indicated the presence of an obstruction of the intrahepatic bile ducts, disruption of the liver architecture or hemolytic anemia [39, 42]. Thus, the results recorded in this study suggest that CE altered the liver and biliary tracts architectures and functions. Differently, the results of biochemical examination for nephric parameters could not explain the marked histological changes of the kidney. The sub-acute treatment with CE did not induce any significant change in creatinine level: the major biological marker of renal dysfunction [43]. However, a significant increase in uric acid in serum was noted which can be explained by the elevation of the protein degradation [44].

Liver is the site of cholesterol disposal or degradation and its major site of synthesis. In the same perspective, the liver controls glucose synthesis and generates free glucose from hepatic glycogen stores. As no significant changes were observed in glucose and cholesterol levels in this study, this suggests that CE had no effects on the lipid and carbohydrate metabolism of the mice. The other biochemical parameters such as TP and TG showed no significant changes between treated and control groups.

A wide spectrum of beneficial and toxicological effects of $P$. harmala is attributed to the presence of many bioactive compounds especially alkaloids. These alkaloids are mainly comprised of $\beta$-carboline and quinazoline derivatives [16, 17, and 18]. They have neuro-pharmacological and toxicological properties such as inhibition of MAO-A [19, 20 and 21] and AChE [22]. All together, these neuropharmacological properties may be used to explain mortality and signs of intoxication during the acute toxicity study with higher doses of CE. In addition, $\beta$-carboliniques alkaloids may have not only neurotic actions but also cytotoxic ones. Nafisi et al. [1] and Sobhani et al. [45] proved that can $\beta$ carboliniques alkaloids could intercalate between nitrogenous bases of the DNA leading to the inhibition of DNA topoisomerase I, and therefore, the inhibition of DNA replication and cell division.

\section{CONCLUSION}

In conclusion, we showed that $P$. harmala could be lightly toxic according to the consumed doses in Algerian folk medicine. However, at higher doses and for long time exposure, the seeds extracts can cause several hepatic and nephritic toxicities.

\section{REFERENCES}

1. Nafisi S., Bonsaii M., Maali P., Khalilzadeh M. A., \& Manouchehri F. Beta-carboline alkaloids bind DNA. Journal of Photochemistry and Photobiology B: Biology, 2010; 100:84-91.

2. Yousefi R., Ghaffarifar F., \& Dalimi A. A. The Effect of Alkanna tincturia and Peganum harmala Extracts on Leishmania major (MRHO/IR/75/ER) in vitro. Iranian Journal of Parasitology, 2009; 4:40-47.

3. Duke A. J. Handbook of Medicinal Plants. 2nd ed. CRC Press (Boca Raton, Florida), 2002; 717.

4. Farouk L., Laroubi A., Ouachrif A., Aboufatima R., Benharref A., \& Chait A. Study on Antinociceptive Activity of Different Extracts of Peganum Harmala and Possible Mechanism of Action. Iranian Journal of Pharmacology and Therapeutics, 2009; 8:29-35.

5. Monsef H. R., Ghobadi A., Iranshahi M., \& Abdollahi M. Antinociceptive effects of Peganum harmala L. alkaloid extract on mouse formalin test. Journal of Pharmacology and Pharmaceutical Science, 2004; 7:65-69.

6. Singh B. A., Chaturvedi J. P., Narender T., \& Srivastava, K. A. Preliminary studies on the hypoglycemic effect of Peganum harmala l. Seeds ethanol extract on normal and streptozotocin induced diabetic rats. Indian Journal of Clinical Biochemistry, 2008; 23:391-393.

7. Shi C. C., Liao J. F., \& Chen C. F. Comparative study on the vasorelaxant effects of three harmala alkaloids in vitro. Japenease Journal of Pharmacology, 2001; 85:299-305.

8. Baghiani A., Djarmouni M., Boumerfeg S., Trabsa H., Charef N., Khennouf S., \& Arrar L. Xanthine Oxidase Inhibition and Antioxidant Effects of Peganum harmala Seed Extracts. European Journal of Medicinal Plants, 2012; 1:42-56.

9. Nenaah, G. Antibacterial and antifungal activities of (beta)carboline alkaloids of Peganum harmala (L) seeds and their combination effects. Fitoterapia, 2010; 81:779-782. 
10. Kiani S. J., Shamsi S. M., Ataei A., \& Sajjadi N. Peganum harmala seed extract can prevent HSV-1 replication in vitro. Iranian Journal of Virology, 2008; 4:11-16.

11. Mahmoudian M., Jalilpour H., \& Salehian P. Toxicity of Peganum harmala: Review and a Case Report. Iranian Journal of Pharmacology, 2002; 1:1-4.

12. Frison G., Favretto D., Zancanaro F., Fazzin G., \& Ferrara S. D. A case of $ß$-carboline alkaloid intoxication following ingestion of Peganum harmala seed extract. Forensic Science International, 2008; 179:e37-e43.

13. Kurachko K., Umarov A., \& Markman A. The oil of the seeds of Peganum harmala. Chemistry of Natural Compounds, 1969; 5:358-359.

14. Agedilova, M., Turmukhambetov, A., Schultz, E., Shakirov, M., \& Adekenov, S. Components of the aerial part of Peganum harmala. Chemistry of Natural Compounds, 2006; 42:226-227.

15. El Allagui N., Bourijate M., Tahrouch S., \& Hatimi, A. Effect de cinq extraits végétaux sur meloidogyne spp de la tomate. Congrés Internationel de Biochimie (Agadir), 2006; 357-360.

16. Kartal M., Altun M. L., \& Kurucu S. HPLC method for the analysis of harmol, harmalol, harmine and harmaline in the seeds of Peganum harmala L. Journal of Pharmcological and Biomedical Analysis, 2003; 31:263-269.

17. Khashimov K., Telezhenetskaya M., \& Yunusov S. Desoxypeganine: A new alkaloid from Peganum harmala. Chemistry of Natural Compounds, 1969; 5:381-382.

18. Zharekeev B., Khashimov K., Telezhenetskaya M., \& Yunusov S. New alkaloids from Peganum harmala. Chemistry of Natural Compounds, 1974; 10:282-283.

19. Kim H., Sablin S. O., \& Ramsay R.R. Inhibition of monoamine oxidase A by beta-carboline derivatives. Archives of Biochemistery and Biophysics, 1997; 337:137-142.

20. Herraiz T., \& Chaparro C. Human monoamine oxidase is inhibited by tobacco smoke: beta-carboline alkaloids act as potent and reversible inhibitors. Biochemical and Biophysics Researchs Communuty, 2005; 326:378-386.

21. Herraiz T., González D., Ancìn-Azpilicueta, C., Arán, V. J., \& Guillén, H. ß-Carboline alkaloids in Peganum harmala and inhibition of human monoamine oxidase (MAO). Food and Chemical Toxicology, 2010; 48:839-845.

22. Tuliaganov N., Sadritdinov F. S., \& Suleimanova, G. A Pharmacological characteristics of desoxypeganine hydrochloride (Abstract). Farmakol Toksikol, 1986; 49:37-40.

23. Tahraoui A., Israili Z. H., \& Lyoussi B. Acute and sub-chronic toxicity of a lyophilised aqueous extract of Centaurium erythraea in rodents. Journal of Ethnopharmacology, 2010; 132:48-55.

24. Randhawa M. A. Calculation of LD50 values from the Method of Miller and Tainter, 1944 (Letter to Editor). Journal of Ayub Medical College AbbottAbad, 2009; 21:184-185.

25. Hsu Y., Tsai C. F., Chen W. K., Huang C. F., \& Yen C. C. A subacute toxicity evaluation of green tea (Camellia sinensis) extract in mice. Food and Chemical Toxicology, 2011; 49:26242630.

26. Bensalem-bendjelloul, M. Techniques histologiques théorie et pratique. Office des publications universitaires, 1998; 6-41.

27. Hodgson, E., \& Cunny, H. (2010). Toxicity Testing. In: A Textbook of Modern Toxicology. 4th ed. John Wiley \& Sons. Inc (Hoboken, New Jersey), 409-456.

28. Frank C. L. U. (1992). Toxicologie, Données générales, procédures d'évaluation, organes cibles, évaluation du risque. (Paris), 73-202.

29. Lamchouri F., Settaf A., Cherrah Y., El Hamidi M., Tligui N. S., Lyoussi B., \& Hassar M. Experimental toxicity of Peganum harmala seeds (Abstract). Annales Pharmaceutiques Françaises, 2002; 60:123-129.
30. Mukinda J. T., \& Syce J. A. Acute and chronic toxicity of the aqueous extract of Artemisia afra in rodents. Journal of Ethnopharmacology, 2007; 112:138-144.

31. Li X., Luo Y., Wang L., Li Y., Shi Y., Cui Y., \& Xue M. Acute and subacute toxicity of ethanol extracts from Salvia przewalski Maxim in rodents. Journal of Ethnopharmacology, 2010; $131: 110-115$.

32. Rhiouani H., El-Hilaly J., Israili Z. H., \& Lyoussi B. Acute and sub-chronic toxicity of an aqueous extract of the leaves of Herniaria glabra in rodents. Journal of Ethnopharmacology, 2008; 118:378-386.

33. Olson H., Betton G., Robinson D., Thomas K., Monro A., Kolaja G., Lilly P., Sanders J., Sipes G., Bracken W., Dorato M., Van Deun K., Smith P., Berger B., \& Heller A. Concordance of the Toxicity of Pharmaceuticals in Humans and in Animals. Regulatory Toxicology and Pharmacology, 2000; 32:56-67.

34. Muhi-eldeen Z., Al-Shamma K. J., Al- Hussainy T. M., Al- Kaissi E. N., Al-Daraji A. M., \& Ibrahim, H. Acute Toxicological Studies on the Extract of Iraqi Peganum Harmala in Rats. European Journal of Scientific Research, 2008; 22:494-500.

35. Hariri A. T., Moallem S. A., Mahmoudi M., \& Hosseinzadeh H. The effect of crocin and safranal, constituents of saffron, against subacute effect of diazinon on hematological and genotoxicity indices in rats. Phytomedicine, 2011; 18:499-504.

36. Khalil A. H., \& El-Adawy T. A. Isolation, identification and toxicity of saponin from different legumes. Food Chemistry, 1994; 50:197-201.

37. Arias M., Quijano J. C., Haridas V., Gutterman J. U., \& Lemeshko V. V. Red blood cell permeabilization by hypotonic treatments, saponin, and anticancer avicins. Biochimica et Biophysica Acta, 2010; 1798:1189-1196.

38. Qin Y., Wu X., Huang W., Gong G., Li D., He Y., \& Zhao Y. Acute toxicity and sub-chronic toxicity of steroidal saponins from Dioscorea zingiberensis C.H. Wright in rodents. Journal of Ethnopharmacology, 2009; 126:543-550.

39. Atsamo A. D., Nguelefack T. B., Datté J. Y., \& Kamanyi A. Acute and subchronic oral toxicity assessment of the aqueous extract from the stem bark of Erythrina senegalensis DC (Fabaceae) in rodents. Journal of Ethnopharmacology, 2011; 134:697-702.

40. Wallace A. D., \& Meyer S. A. Hepatotoxicity. In: A Textbook of Modern Toxicology. 4th ed. John Wiley \& Sons. Inc (Hoboken, New Jersey), 2010; 277-290.

41. Akhtar A., Deshmukh A. A., Raut C. G., Somkuwar A. P., \& Bhagat S. S. Prallethrin induced serum biochemical changes in Wistar rats. Pesticide Biochemistry and Physiology, 2012; 102:160-168.

42. Hor S. Y., Ahmad M., Farsi E., Lim C. P., Asmawi M. Z., \& Yam M. F. Acute and subchronic oral toxicity of Coriolus versicolor standardized water extract in Sprague-Dawley rats. Journal of Ethnopharmacology, 2011; 137:1067-1076.

43. Jodynis-Liebert J., Nowicki M., Murias M., Adamska T., Ewertowska M., Kujawska M., Piotrowska H., Konwerska A., Ostalska-Nowicka D., \& Pernak J. Cytotoxicity, acute and subchronic toxicity of ionic liquid, didecyldimethylammonium saccharinate, in rats. Regulatory Toxicology and Pharmacology, 2010; 57:266-273.

44. Lùllmann H., Mohr K., \& Ziegler A. Atlas de poche de pharmacologie. 2nd ed. Médecine-Sciences, Flammarion (Paris), 1998; 32-42.

45. Sobhani A. M., Ebrahimi S. A., \& Mahmoudian M. An in vitro evaluation of human DNA topoisomerase I inhibition by Peganum harmala L. seeds extract and its beta-carboline alkaloids. Journal of Pharmacology and Pharmaceutical Science, 2002; 5:19-23. 